\title{
Internalising Negative Self-Image Externalities: The First Objective for City Marketing as a Municipal Management Tool ${ }^{1}$
}

\author{
Manuel Escourido Calvo*, Antonio Javier Prado Domínguez, Valentín Alejandro Martínez Fernández
}

Faculty of Economics and Business, A Coruña University, 15008, Spain

\begin{tabular}{l} 
A R T I C L E I N F O \\
\hline Article history: \\
Received: 26 November, 2019 \\
Accepted: 04 January, 2020 \\
Online: 15 January, 2020 \\
\hline Keywords: \\
city marketing \\
externality \\
self-image \\
sense/pride of belonging \\
perception
\end{tabular}

\begin{abstract}
A B S T R A C T
In times of crisis or traumatic transformation processes, one of the most frequent negative externalities is that the self-image of a city deteriorates among its stakeholders, which affects their economic and social expectations and decisions. The internalisation of this externality must be a key objective for the local public manager so that any initiative can be carried out with collective support and collaboration. When applied to this end, city marketing and the instruments that this technology makes available to city managers provide optimal results.
\end{abstract}

\section{Introduction}

From a historical perspective, cities are understood as the domains of human interaction in which civilisation develops; for this reason, they play a role in supporting economic activity [1]. In fact, an economic analysis of civilisation must take into account its concreteness: that is to say, the city itself. This is the reason why many disciplines approached the subject through the study of the city and its management, knowing full well "the city is, manifestly, something very complex" [2].

The importance of "good" city management is manifest, above all, in times of economic crisis. The crisis of 1973 led to the adoption of a new conceptual framework for city management during a time of restructuration, with a need for social policies aimed at job creation, urban renewal policies and economic policies focused on externalities. Years later, the 1990's industrial depression meant that the city had to make city management decisions based on new technologies, innovation and the negative impact externalities had on urban ecosystems.

Urban managers began to acknowledge the importance of remaining competitive in the city global market during the 2008 crisis under the threat of population decline, unemployment or the loss of investment in favour of more competitive cities.

\footnotetext{
*Manuel Escourido Calvo, Email: manuel.escourido@udc.es

${ }^{1}$ This paper is an extension of work originally presented in the 2019 14th Iberian Conference on Information Systems and Technologies (CISTI)
}

The city is the crossroad where interests and actions meet and where economic, social, urban and environmental conflicts are expressed with great intensity. When this scenario depends on the fate of industry or industrial groups and resources and/or local produce is in decline- in terms of job creation and invigoration or economic engine- the challenge is even greater.

This has happened in many cities that went through and/or have ongoing industrial restructuring or termination/closure procedures related to the natural resources on which they were dependent. In turn their downfall triggers a demographic threat, with the loss of population in the age bracket that has the biggest impact on birth rates. Decline can also be expressed in economic terms with the loss of future, high quality taxable base income, added value workers, entrepreneurs and externalities, as well as in social terms, with an overall loss of talent.

As explained in research by Escourido, M. [3], which is part of his $\mathrm{PhD}$ thesis, this environmental change and foundational transformation of the city resulted in an enormous amount of public funding being spent on discretionary actions in an effort to solve a multifaceted problem with only one solution. The problem was coupled with the absence of a systematic and competitive diagnosis of the city and a much needed strategic thinking process focused on both supply and demand. These actions were detached from any planning and had no impact on the city, although political marketing slightly benefited by them. 
The process of change facing the city this century happen in such a quick and constant pace that, in many cases, the community is overwhelmed and unable to react. If there are ongoing, dramatic situations in the city, the challenge is greater. Nevertheless, cities in decline and lacking in expectations also have citizens asking for solutions to problems related to employment, education, safety and social services. Their demands reach urban managers. It is these public servants who must allocate suitable services to meet their needs and improve the ranking of their city. Being unsuccessful in meeting these goals means that locals can "vote with their feet" [4].

We must not forget that cities are made up of the people who define them, adding dimensions and guiding them to their future. This is why problematic areas are not only those with business or industry in decline, but also those where people think the future will be the same as today [5].

We are then looking at city management with certain features. Its social and economic development process originated from public sector activity, such as in a state energy policy and/or industrialization. Moreover, the economic industrial monoculture model drifted because the market and the comparative competitiveness of factors and sectors went into decline. Even if this trend had been caused by market failure, it suggest that the public sector had erred in its passivity [6].

On the other hand, interventionist measures are overlooked or left incomplete when the city is faced with a socioeconomic change of such magnitude that it leads to a series of negative consequences. Among these outcomes are a highly negative externality and an absence of expectations. Another is the negative self-image of the city, which mirrors its dwindling attractiveness and its social and economic decay. These problems can be offset by changing how the city is perceived with marketing based on urban management tools funded with public-private collaboration formulae.

\section{Coase and the externality internalization (solution)}

State intervention through regulations, bans and taxation is the usual response to the externalities problem [7], always under the wrong However, in doing so, the public sector determines legal responsibilities instead of clarifying the economic nature of the problem. Thus, the system's efficiency may be diminished.

This happens because the State and courts argue over who has the right to take action rather than decide what should be done. These initial legal rights boundaries can always be modified through market transactions, redefining themselves in the process if this leads to increased production.

At this point, one can follow the thinking of Coase. He refers to, but questions, the assumption that there are pre-existing property rights, assigned and defined in a clear manner, with inexistent or low transaction costs. Enshrined in law, these property rights are in conflict with a viable and efficient economic solution. Thus they would be reallocated towards those who value them the most, even if the legal system goes against them.

With zero transaction costs, economic agents would elaborate the contractual ruling necessary to maximise production value, whatever the nature of these circumstances may be: legal, with liabilities or through wealth distribution. At the same time, Coase [8] states that, when real costs are generated and must be accounted for, many of these agreements and deals may be annulled because their cost would be higher than the income generated.

Taking into account transaction costs, Coase points out that both parties may feel their incentives are lessened when the information needed to carry out deals and agreements have been revealed. Public intervention would be needed to define which incentives are missing or which contractual deals can be done. Even in the case of exceedingly high transaction costs, state intervention can protect specific activities that are causing harmful externalities.

In this context, a point may have been overlooked: communal private property- mainly business- is defined as a system aimed at minimizing transaction costs, even more so in complex social environments.

In conclusion, this is a general balance model for a market economy, whose theoretical underpinnings are closer to being defined. They aim at maximizing efficiency, without taking into account the reason or use of property rights. The State still has the right to act when transactions have high cost or pose difficulties. Otherwise, these agreements will be untenable. Another advantage of the Coase Theorem is that the aforementioned situation is suitable for the externalities of production or consumption. It also comes into play in cases of inaction, when a forest has not been maintained properly or if a government fails to foresee the socioeconomic consequences of a declining industrial monoculture.

Nevertheless, Coase warns that the proposition is weakened by the sense of instability in the balance; the economy is defined as a process, not a state.

With these arguments in mind and heeding Cooter and Ulen [9], one may reach the conclusion that the State's main function is be to minimise the cost of every economic transaction, wherever it may be. In most cases, property rights would be clearly defined. This principle, known as Coase's Normative Theorem, means that law is structured "in such a way that nothing prevents private agreements from being reached". Apart from facilitating and promoting deals, it should minimise losses caused by the lack of deals $[10]$.

\section{Including the particularities of subjectivism and perception in internalising (solving) externalities.}

Some of the objections to Coase's Theorem are related to the concept of human preferences. These objections, like human preferences, can be subjective, dynamic, shifting and therefore not measurable or comparable. Every market agent would try to increase their "psychological profits" in search of solutions that make them possible. This is mostly a problem of information and perception, as well as a strategic game and aversion to risk. Even taking zero transaction costs into account and properly defining private property rights, the potential possibilities of each deal would have to be taken into account to solve an externality.

As stated by Hayek [11], social science measures human perception around the world in terms of people's beliefs. A true or false perspective cannot be observed directly; the speech and 
actions of an individual, however, can be studied. Human actions are not an objective fact: they are what the person performing them believes those action do, and so they form part of a personal, individual perception. Therefore, the perception of goals and means is introduced as an element to consider when solving externalities.

The same applies to cost and risk perception because the elements of individual choice depend on new ideas and are taken into consideration by the person who decides them and his or her preferences [12]. It is worth noting that, in a current behavioral analysis of Coase's Theorem, one of the results, among others, suggest that, when an "unfair offer" is presented, the desire to break negotiations is so strong that the Theorem does not apply, even when it is against the self-interests of the individual rejecting the offer [13].

It is therefore possible to ascertain that social cost and social products are not objective concepts; different individuals consider benefits and prejudices based on their own perceptions, presumptions and analysis. This means efficiency in the choices made cannot be assessed in an objective way.

At this point, the market has tools- including profit and competition as motives- which provide the incentives needed to define and then meet the needs and desires of consumers. The successful provider earns profits, supplanting the others who fail at this task. These tools do not guarantee that the correct choices are always made, because they cannot be known. However, in the long run, it is expected that these same tools optimise the social net benefit [14].

Public sector management must step in at this point so that it can identify, prioritise, and meet the needs and demands of clients or those managed. To this end, marketing as an urban management tool should be adopted. With the paradigm shift ushered in by New Public Management, the administration focuses on the "clientcitizen". The end result is custom-made solutions for citizens, not only in the domain of goods and services but also in the promotion and creation of incentives, particular conducts and desirable perceptions, such as those contributing to the internalisation of specific externalities.

\section{Externalities of negative self-image. As Pontes de García Rodríguez (Spain) as a case in point}

To favour industrialisation and empower energy production, state economic intervention during the 1970's in Spain favoured lignite mining in As Pontes de García Rodríguez (A Coruña, Galicia, NW Spain). This was done in an open pit mining operation. The mineral was then used as fuel in a power plant that was built by the public sector in the same city. A public company was responsible for the project: Endesa (Empresa Nacional de Electricidad SA). In what had once been a rural city, a period of demographic and economic expansion began. It had a striking impact on the income and wealth of the area.

On the one hand, expropriations were carried out to establish the mining operation, which provided unimaginable wealth to mostly rural land owners with forests, crops and livestock. In many cases, this change also meant access to what resembled public employee posts in the mines, power plant or the services attached to them. Moreover, salaries were well above the average www.astesj.com national wage, with complements and benefits: the state paid for accommodation, schooling for employees' children and workers' personal electricity bills. In the same fashion, the income generated by this company in the public treasury meant the council budget continued to grow. As a result, an infrastructure was created to support services whose quality was higher compared to that in other cities of similar size and population.

However, all the mining operations and power plant activity overshadowed local businesses due to a difference in employment opportunities and salaries offered by Endesa. A great amount of resources was allocated towards this company. The primary sector, in contrast, was practically reduced to subsistence farming of crops and livestock in those places where the land was not expropriated by the state for mining. On the other hand, the construction sector developed small companies driven by the high demand for housing for the newly arrived workers for the mines and power plant.

Nevertheless, this development was limited by Endesa itself as it was a public company back then. Endesa built over a thousand homes for employees and their families in exchange for a symbolic rent. At the same time, an auxiliary and service industry for repairs, maintenance and supplies emerged, linked to and dependant on mining and energy production. This sector had a presence in commerce, thanks to many catering services.

This situation of extreme economic dynamism in the municipality and surrounding areas and the positive externality resulting from public sector intervention made a complete turnaround after two events. Firstly, the mining operation was closed in December 2007 in accordance with European Union directives. The second event is the worldwide crisis, as experienced in As Pontes de García Rodríguez, especially from 2012 onwards. The shift in focus of environmental legislation in the European Union conveys a negative externality leading to the direct closure of the mining operation in this municipality. Even more, it was known that lignite exploitation would be curtailed and public intervention was limited or non-existent so little effort was made to minimise the risks arising from a social and economic industrial monoculture with a limited lifespan.

Since then the city has felt the effects of socioeconomic decline: unemployment, retirement and early retirement from the mining operation, a lack of opportunities for the younger population brackets with higher education and the failure of reindustrialisation initiatives despite having the advantages of heavy public funding. Moreover, in the absence of planning and management, the different public administrations have been unable to turn the tide in a place that was "killed by its own success".

In turn, the city faces a demographic threat with a loss of population in the age bracket that has the biggest impact on birth rates; an economic threat with loss of future high quality taxable base income, added value workers, entrepreneurs and externalities and also a social one with an overall loss of talent. These threat were paired with the disappearance of retired workers and their retirement and early retirement pensions. This led to the risk of an urban decay process: reduced population, fewer services, more taxes and a less stable population. 
As Pontes de García Rodríguez represents many of the points mentioned earlier:

- Here, city management focused on public-financed social and economic development from the public sector leading to positive externalities.

- However, in the absence of a collective vision for the city, public management failed to exploit multiple synergies while they were still viable to break away from the economic model of a monocultural industrial reality.

- There were clear indications of the public sector's passive attitude, whose intervention was non-existent, incomplete or misguided when challenged with a socioeconomic process of decline on such a large scale.

- Its most striking externalities (at least in regards to the priority that its internalisation must have) demonstrate a lack of expectations and negative self-image of their local population.

In fact, research was carried out by Escourido [3] through telephone conversations in a poll with a sample of 9,451 residents over 16 years of age, with a confidence level of $95 \%$ and $5 \%$ maximum sample error margin. Also interviewed was a panel of city representatives (Delphi, with total of 21 individuals). This study reveals low expectations with regards to the future of the city, based on the perception of the citizens.

This is considered a city with an ongoing deindustrialisation phase and a decadent image. Moreover there was a sensation of improvisation and inability from the public sector, as well a lack of social cohesion brought on by the duality between retired/early retired miners with high pensions and the rest of the population, affected by the loss of employment.

The internalisation (solution) of an externality closely related to the perceptions, desires and needs of the individuals has to take into account the need for public intervention aimed at reducing or eliminating transaction costs (information, property rights reallocation and negotiation). This must be carried out with the use of public and private collaboration mechanisms, marketing technology tools for cities which boost its self-image and strengthen a sense of belonging to the city. All of these measures are essential to develop subsequent socioeconomic recovery initiatives.

\section{City marketing as a tool for public management to internalise the externalities of negative self-image. Case study of As Pontes de García Rodríguez (A Coruña).}

Traditionally public management appeals to the political process for resource allocation; criteria include redistribution, equity, the common good or general interest. The level of focus depends on plurality, as well as administrative and executive fragmentation. Allocation, therefore, comes from legal actions and processes. In value creation, many factors are taken into account. These are variety and attachment, as well as transparency, zero discrimination, legality and social perceptions. This is especially true when the administered citizen acknowledges that the collective interest is not the sum total of all the individual interest, contrary to the way it is in the market when the word "client" is mentioned.

With economic efficiency goals -such as continuous improvement, resource utilisation and process based organised structure- and the citizen-client service, public management is more than a sovereign, coercive instrument. Instead, it has the end goal of providing services for society, such as identifying citizen needs and meeting them in an efficient and successful manner and with the highest possible quality. Marketing then becomes a technology that is adopted from the private sector for the public administration, to work as a detector and a way to measure the needs of the target market. Services can thus be developed to meet their needs and prepare for the upcoming changes. Every step is done in an efficient and successful way under the guidance of its vision, mission and values and goals.

This is the major advantage of city marketing when it is compared to other planning tools. The traditional focus of supply is supported by one of demand. This mechanism can spot and solve current needs by providing adequate services and infrastructure and future ones as well by developing new assets to improve living standards and keep competitive advantages in the target markets and establish communication in a way that a city brand is built. Moreover, the focus on demand allows for a more realistic and less resource intensive framework of action, with advantages derived from its efficiency.

One of the goals of city marketing is to improve and develop a positive city image [15]. Image has an enormous impact on city life as a "determining factor in urban development" [16]. This can become either a huge supporting factor or obstacle for the economic, cultural and social development of a city. It is considered a high importance "asset" in the development of city management [17].

This city image is built upon when defining its "vision". This is a must when planning projects based on demand (target market) and on identity resources. These are ideal for creating a guaranteed difference in the product [18]. The results will depend on the accuracy of the identity perception and the suitability of how the demand is adapted to each case. It is important to know beforehand the image of the city from the perspective of its locals and users: self-image is the starting point. Once the self-image is known, differences between the city's goals and those of its citizens, business and institutions can be asserted.

As mentioned above, if the starting point is a negative selfimage of the city-no matter the origin of these externalities- the top priority should be to modify and restore the self-image in a positive way. This is also to restore a sense of belonging, along with local pride, to the city. It is the only way to make citizens take part in restoring the city and bring stakeholders back to plan for its future vision. With city marketing, the first objective is to define the city project based on the demand for its identified resources. This is the reason why a positive internal perception is needed in the city to minimise risks while elaborating future plans.

It is true that certain tangible elements of the city are required, like infrastructure or services, but these are not enough anymore. Nowadays intangible resources are what adds value and makes a 
difference [19] when planning how to manage its capacity to attract people, investors, business, administration and tourism. In this sense, the top priority must be to fortify citizen-city relationships. The opinion of satisfied citizens about the city where they live creates a positive self-image of that city. Making sure every citizen has a certain living standard and services that meet their expectations and desires transforms them into active communicators of the city when they are outside of it. That is why it is vital to analyse the self-image of the city, to reinforce it or to correct a possible negative value.

When image policies are supported in a realistic vision of the city and the active participation of all its citizens is promoted by the administration, a brand image is created in a stronger, more efficient fashion. This is the opposite of a brand created solely by the local public servants. Image policy must strike a balance between image and quality of life, jointly coordinated by those responsible for that image policy, citizens and the municipal government.

Management of the image falls into the hands of its inhabitants, who are the inside target market, a vital task with the goal of fixing, improving and restoring a city's self-image. If the different inside target markets of the city are satisfied with or proud of the city they live in, they in turn help to make a better image and positive brand. If living standards, along with the social, cultural and economic environment, meet the diverse needs of citizens, business, and local institutions, each one of them will become a definer- or in marketing terms, a "preacher"- of the city brand.

To achieve this, internal communication must be suitably systematised so that information flows and positive effects are generated among all citizens and institutions within the city. This strengthens the values associated with pride and sense of belonging to or living in the city, innovation and change. Also, a positive self-image is the lever needed to involve, motivate and engage the stakeholders of the city with the city project. In the best case scenario, this project will be the product of participation, general agreement and internalisation.

This is a bottom-up approach, where city marketing expands the possibilities of strategic management and provides local authorities their participation in the hearings, discussions and decision making those groups and sections of the population who detect and pose in front of city problems [20], starting with the solution for the negative self-image.

In the case of As Pontes de García Rodríguez, there is access to different tools and resources to accomplish this internal communication. The city also has to confront one of the greatest challenges during the research phase. In particular, the panel of city representatives has to counter the existing negative connotations of the city's self-image. What the city is for its internal target markets and what they would like the city to be is an aspiration that must be present at all times. At the planning stage of the strategic city marketing, this must be true. These ideas must also inform the operational stage, when deciding which actions should be taken to meet the needs detected in the target markets of the city.
When the City Marketing Plan and all the measures mentioned in it are implemented, a general agreement must exist, with all public and private officers involved. This guarantees the continuity of the plan far beyond electoral horizons. The marketing applied to city planning means a long-term strategy aimed at creating new competitive advantages, one of which is the city brand itself. Also needed is the general support of all public and private agents within the city. To accomplish this, the contents of this plan must be agreed on by everyone and widely disseminated. Every strategic option planned for the city must have the approval of its stakeholders to avoid their rejection and with it the failure of its implementation.

The city and its planning are not described in terms of economic productivity and capacities. Instead, the focus should be on its attractiveness and the city's position in different global networks; this approach requires considerable collaborative and creative input. With the use of city marketing as a tool for local public management, interest (or what it is expressed as value) is the potential on a micro scale (the city) and as such it can be adapted to a macro scale (international flow system) to achieve a position as an attractive and well placed city in the global network. To do this, the city brand and its self-image and territorial coherence are essential, as is the sense of belonging, identity and planning to achieve it.

All without forgetting that the image of the city can be defined as organic, in continuous change [21]. If this image is negative (for example, after a process of long industrial decline), it requires a comprehensive application of city marketing (and not just advertising). This is because it is necessary to modify the selfimage of the inhabitants to then be able to involve them in the transformation process that the city needs.

In this particular case (described in point 4), to improve selfimage as well as recover self-esteem and sense of belonging among citizens, there is a series of measures that are to be carried out using city marketing as a tool for local public management [22] wich provides solutions for negative externalities. To correct these externalities, steps include [3]:

a) Building a city network. The objective is to create a configuration of networks allowing pressure groups to claim leadership positions and promote cities in a broad and ambitious way. It serves as a tool for implementing advanced technologies to gain access to a larger volume of information and exchange experiences at every city management level about supply and services, government, efficiency and management quality, environment and other topics. This involves integrating into and being part of an urban economic type network to find solutions to common problems and identify competitive advantages or share urban innovations. With cultural concerns, there can be promotion and defence of joint interests. The tourist domain is to promote tourism, culture, history and the environment, while the social content is about promoting values and cooperation. This is a communication and management tool for external projection, making the city more attractive and, above all, improving its selfimage. The associations around an exemplary city and its attributes improve its perceived image both in- and outside that place. 
b) Promoting local heritage. The historic, natural and industrial heritage in As Pontes de García Rodríguez is an element that connects past, present and future and projects the city's identity as a collective and/or a city. The footprints left behind by history, human interaction with nature and intense industrial activity in the area are a common link that can be used as a powerful tool to educate, build awareness and communicate in terms of an identity, an image and/or a brand. This natural and industrial heritage is used to preserve identity and self-image, while maintaining the continuity of the community and, at the same time, generating the right to use it and the collective duty of preserving it for the future.

A plan must be put in place to emphasise the value of its historic heritage, with archaeological sites from the Palaeolithic and Neolithic age, Roman period objects and bridge and the noble patronage of García Rodríguez de Valcárcel; its natural heritage, with is natural park in the Fragas do Eume region, lake, coal heaps, A Ribeira and Eume reservoirs and Caxado hills; and industrial heritage linked to mining operations and their industrial development. A process is needed to select what is of value and determine the next steps in incorporating collective identity and the actions that have to be taken to preserve and promote it.

It is important not to lose sight of the interpretation and value of these elements. This is done through logic, interests and perceptions because the planning must take into account general agreements about concepts, management models and valuedeposed formulae.

c) Reclaiming talent. Building awareness to raise the level of talent inside the city lets it improve its self-image, as well as develop a sense of belonging and a collective pride. To shift perceptions and make the city more attractive to locals, eventssuch as conventions, shows and meetings- can be held to gather local people who excel professionally and have management positions in business or organisations.

d) Mobilise and bond with the migrants. As Pontes de García Rodríguez lived through the same migrations as the rest of Galicia during the end of the 19th century and beginning of the 20th (mostly migrants that went to South America) and again during the 50s and 60s (to South America and Centre of Europe). Later, the mining operations and power station made by Endesa, combined with the economic boom, allowed the vast majority of young people to have access to training and education at all levels showcasing a high percentage of citizens that reached higher education. Most of those students failed to find a job in their local city so they went to other areas.

At this point, the goal is to facilitate communication channels between "ponteses" (As Pontes locals) who are outside the city and keep and promote ties with the city. This measure can become an ideal economic, social and cultural tool among the members of the city and the institutions. These goals help to develop the city identity of the locals and their environment (family, social and economic); outside perception improves as the self-image of the locals gets better.

As shown, the courses of action proposed are aimed at public and private interests alike, during a time when people are solving public problems based on perceptions and personal feelings. This entails taking measures and holding discourse that brings satisfaction and meets needs. Also needed are a public worldview and narrative discourses (even political ones) that go deeper into the construction of the city from the public sector perspective.

With all of these points seen as tools for city marketing, the city is a space and an ensemble of meanings that are shaped and given function and purpose as the social agents relate to each other. They create a space to understand the diverse ways to express oneself, interpret symbols and produce meaning. This is where every audience is built from the collective senses, cooperation towards social change and encouragement of positive self-image and city pride.

Our perception of the world is almost always local, focusing, exclusively, on what is around us and our neighbourhoods, traditions and beliefs. At the same time, aspirations exist in all of our levels of society, from the lowest to the highest. Every one of us sends signals that express belonging to a tribe. If the big brands appeals to perceptions, needs, desires and feelings or hope, attractiveness, desirability, love, acceptance, and innovation, the image and brand of a city does not differ. As an individual and also as a citizen, I long for "what we had and lost" and "What we used to dream/be and never had/were" [23]. How we value this longing, evaluating and identifying the city and the image we have of it. To sum up, every community craves a strong sense of belonging and pride, which is the vehicle to any process of social change. This shows the importance of management from the local public perspective, the self-image of the city.

The aphorism "whatever the locals find unattractive outsiders will as well" is especially true in the case of As Pontes de García Rodríguez, as shown in the cited research. The appeal to city marketing from a public management perspective makes it possible, among other things, to act upon the immaterial values or intangibles of the city, in such a way that the self-image of the city shifts into something attractive for the residents. And it makes it possible, even in its application to small and medium-sized cities [24].

To do this, improving the reputation and citizen self-esteem, achieving a welcoming social environment open to innovation and lower the resistance to change (or adaptation) are the first steps needed to lay the foundations. Thus the main goal of public marketing is reached: enhancing the attractiveness of the city.

\section{Conclussions}

The importance of "good" management of the city is manifest, especially during a crisis. Traditional strategic planning focused on supply is not enough. An approach that focuses on demand is needed, along with the use of a city marketing technology.

In cities where the last recession has generated traumatic processes in terms of restructuring or the social and/or economic fabric has disappeared especially when they once enjoyed times of intense economic growth, one of the negative externalities with highest impact is the emergence of a negative self-image in the city. This in turns affects the city brand, expectations and decisions of its stakeholders and, with them, the future development of the city itself. 
These externalities come from market failures and/or public sector mistakes and require public intervention to minimise or eliminate transaction costs, as Coase pointed out. Taking into account the nuances of subjectivism and perception management helps internalise (solve) the problem. This should be done by the citizens, and from there, act as a lever to promote social change and the future development of the city. To do this, city marketing used as a public urban management tool can be a solution for these externalities. When it is present, this must be done before implementing the rest of the City Marketing Plan, because the restoration of a positive self-image, pride and sense of belonging is a requirement to mobilise, integrate, involve and engage the stakeholders of the city to help the city reach the "vision" goal via the implementation of the rest of the plan

Every element is present in the case of As Pontes de García Rodríguez (Galicia, NW Spain). Public intervention made an industrial monoculture model that generated wealth and jobs for decades. When this model was exhausted and the state failed to intervene on a suitable scale, the city reached its present situation of decline. This decline is socioeconomic in nature, where the main externality is the generation of a negative self-image of the city, leading to a lack of expectations, depopulation and distrust in public management.

The use of city marketing as a tool for local and public management proposes as the top priority those actions that interiorise (solve) the negative self-image externalities in the city as the first step before anything else is done. This precedes any social or economic change in the city, and has to be done and planned for, taking into account the general approval and participation of the citizens who believe in the future and a vision for their city. This is a bottom-up approach.

It is important to note that marketing and the city are both in a continuous process of change and evolution. For this reason, the diagnosis stage could be carried out at a deeper level and report current perceptions of self-image through the use of new technologies: big/small data, the internet of things or social media.

At the same time, it is necessary to assess in which ways the immaterial aspects of the city gain importance over the material and to see how they flow, influencing the definition of new shapes and forms of city planning and management. This can be done by integrating new methodologies of citizenship participation and social creativity. It would be useful to contrast "city branding" from the point of view of public policy supported by the strategic planning of the city to enhance its capacities and unfold its competitive advantages.

\section{References}

[1] R. Camagni, Economia Urbana, Antoni Bosch Editor, 2005.

[2] D. Harvey, The Urban Experience, Basil Blackwell, 1989.

[3] M. Escourido, "El marketing de ciudades como herramienta de gestión pública local: una aplicación al caso de As Pontes de García Rodríguez (A Coruña)", Ph.D Thesis, A Coruña University, 2017.

[4] C. Tiebout, "A Pure Theory of Local Expediture", The Journal of Political Economy, 64 (5), 416-424, 1956.

[5] P. Kotler, D. Haider, I. Rein, Mercadotecnia de localidades, Ed. Diana, 1994.

[6] D. Weimer, A. Vining, Policy Analysis and Concepts, Prentice Hall, 2004.

[7] A. C. Pigou, The Economics of Welfare, MacMillan, 1932.

[8] R. H. Coase, La empresa, el mercado y la ley, Alianza Ed., 1994.

[9] R. Cooter, T. Ulen, Law and Economics, Harper Collins, 1988.

www.astesj.com
[10] J. M. Aguilera, "El análisis económico del derecho de propiedad: una aproximación", Anuario Jurídico y Económico Escurialense, XLII, 117-128, 2009.

[11] F. A. Hayek, The Sensory Order: An Inquiry into the Foundations of Theoretical Psychology, Kessinger Legacy Reprints, 1952.

[12] L. M. Kirzner, "Competition and Entrepreneurship", University of Chicago Press, 1973.

[13] R. Thaler, Todo lo que he aprendido con la psicología económica: el encuentro entre la economía y la psicología, y sus implicaciones para los individuos, Ed. Deusto, 2016

[14] S. C. Littlechild, "El problema del costo social", Revista Libertas 12, Instituto Universitario Eseade, 1990

[15] M. Escourido, "La marca ciudad: la importancia de su valor", Revista ACEFUDIMA, 2013

[16] R. Friedmann, "Marketing urbano", Contactar, 3, 1999.

[17] M. A. Akbar et al., "An empirical Study Investigation of Task Allocation Process Barriers in the Context of Offshore Software Development Outsourcing: An Organization Size Based Analysis,” Int. J. Comput. Digit. Syst., vol. 8, no. 04, pp. 343-350, 2019.

[18] A. Precedo, M. Escourido, Marketing de ciudades y territorios: una visión renovada, Dextra Ed., 2017.

[19] S. Rivero, "Importancia de los intangibles como motores del crecimiento metropolitano", Curso Gestión Estratégica de Ciudades, Asociación Bilbao Metrópoli 30, 2001.

[20] A. Kiseleva, "Marketing Strategy of the Territory in the Investment Policy of the City", Strategic Management, 22 (1), 22-29, 2017.

[21] G. Hankinson, "Managing Destination Brands: establishing a Theoretical Foundation", Journal of Marketing Management, 25 (1-2), 97-115, 2009.

[22] A. Martin, "Marketing a Municipality as a Place. A Study of Three Municipalities in the north of Sweden", Bachelor Tesis, Lulea University of Technology, 2009.

[23] M. Lindstrom, Small Data, Ed. Deusto, 2016.

[24] N. Dril, A. Galkin, N. Bibik, "Applying City Marketing as a Tool to support Sustainable Development is Samal Cities: case estudy in Ukraine", $2^{\text {nd }}$ International Conference "Green Cities - Green Logistics for Greener Cities", Szczecin, Poland, 2016 